UDC 316.33:321

LBC 60.561 .3

\title{
SOCIAL PREVENTION OF SOCIOPATHIC PHENOMENA IN THE SYSTEM OF ANTIDEVIANT POLICY
}

\author{
Nikolai A. Baranovsky \\ Institute of Sociology of the National Academy of Sciences of Belarus, Minsk, Republic of Belarus
}

\begin{abstract}
Annotation. In modern conditions of the systemic transformation of the Belarusian society, which is developing very slowly and contradictory, despite the steady trend of reducing crime, drunkenness, drug addiction and other negative social deviations, the problem of preventing and combating antisocial phenomena continues to be complex and cause serious public concern. In this regard, the relevance and social significance of empirical studies of antisocial phenomena, their dynamics, the specifics of distribution and determination, the study of the current national legislation and social practice of the state criminological and other antideviant policies are growing. Problems of prevention and counteraction to anti-social phenomena have long attracted the attention of criminologists, sociologists, culturologists, teachers, psychologists and other researchers. However, each historical period of time brings many new circumstances that have an impact on the sociopathic situation. In addition, the persistently high level of antisocial behavior in society in different socio-demographic groups of the population indicates the presence of obvious gaps in the scientific knowledge of this problem, especially in the field of genesis and determination of negative social deviations as well as the lack of effectiveness of the forms and methods of preventive work of social actors, such as law enforcement and other public administration bodies, the family as a social institution, public associations, etc. The author carries out theoretical and applied design of an innovative system of social prevention of antisocial phenomena based on the analysis of statistical data and sociological research. It includes a set of general, special and individual measures of social, victimological and sociopathic, socio-reintegration and legal preventive activities that should be systematically implemented at the social, situational, personality-deviant, personality-victim and personality-socio-interactive levels of social subjectivity. The researcher pays special attention to the state, dynamics and peculiarities of the etiology of the alcohol and drug situation in the country. The authors propose a set of specific social and practical measures to improve the prevention of alcoholism and drug addiction which have a negative impact on the sustainable development of modern Belarusian society.
\end{abstract}

Key words: crime, drunkenness, drug abuse, antisocial phenomena, system of social prevention of antisocial phenomena, antideviant policy.

УДК $316.33: 321$

ББК 60.561 .3

\section{СОЦИАЛЬНАЯ ПРОФИЛАКТИКА АНТИОБЩЕСТВЕННЫХ ЯВЛЕНИЙ В СИСТЕМЕ АНТИДЕВИАНТНОЙ ПОЛИТИКИ}

\author{
Николай Александрович Барановский \\ Институт социологии НАН Беларуси, г. Минск, Республика Беларусь
}

Аннотация. В современных условиях системной трансформации белорусского общества, которая развивается крайне медленно и противоречиво, несмотря на устойчивую тенденцию сокращения преступности, пьянства, наркомании и других негативных социальных девиаций, проблема предупреждения антиобщественных явлений и борьбы с ними продолжает оставаться сложной и вызывает серьезное общественное беспокойство. В связи с этим растет актуальность и социальная значимость эмпирических исследований антиобщественных явлений, их динамики, специфики распространения и детерминации, изучения действующего национального законодательства и социальной практики государственной криминологической и другой антидевиантной политики. Проблемы предупреждения антиобщественных явлений и борьбы с ними 
давно привлекали внимание криминологов, социологов, культурологов, педагогов, психологов и других исследователей. Вместе с тем каждый исторический период времени привносит много новых обстоятельств, которые оказывают влияние на социально-девиантную ситуацию. К тому же устойчиво сохраняющийся в обществе достаточно высокий уровень антиобщественного поведения в разных социально-демографических группах населения говорит о наличии явных пробелов в научных знаниях данной проблемы, особенно в области генезиса и детерминации негативных социальных девиаций, а также о недостаточной эффективности используемых форм и методов профилактической работы социальных субъектов - правоохранительных и других органов государственного управления, семьи как социального института, общественных объединений и др. На основе анализа данных статистики и социологических исследований осуществляется теоретикоприкладное конструирование инновационной системы социальной профилактики антиобщественных явлений. Система включает комплекс общих, специальных и индивидуальных мер социальной, виктимологической и социально-девиантной, социально-реинтеграционной и правовой профилактической деятельности, которые должны системно реализовываться на социальном, ситуационном, личностно-девиантном, личностно-виктимном и личностно-социально-интеракционном уровнях социальной субъектности. Особое внимание обращается на состояние, динамику и особенности этиологии алкогольной и наркотической ситуации в стране. Разработан комплекс конкретных социально-практических мер по совершенствованию профилактики пьянства и наркотизма, которые оказывают негативное воздействие на устойчивое развитие современного белорусского общества.

Ключевые слова: преступность, пьянство, наркомания, антиобщественные явления, система социальной профилактики антиобщественных явлений, антидевиантная политика.

Белорусское общество находится в состоянии системной трансформации, транзитивного развития, что предполагает как позитивные, так и негативные социальные процессы и изменения, противоречивость и неравномерность их протекания. Негативные социальные последствия, включая высокий уровень таких антиобщественных явлений, как преступность, пьянство, наркомания, препятствуют устойчивому развитию страны и представляют угрозу национальной безопасности в социальной сфере.

Государство в последние два десятилетия уделяет большое внимание активизации деятельности по предупреждению антиобщественных явлений и борьбе с ними. Об этом свидетельствует принятие нового национального уголовного, уголовно-процессуального и уголовно-исполнительного законодательства, а также последовательное планирование государственной деятельности в сфере предупреждения преступности, коррупции, пьянства, наркотизма и борьбы с этими явлениями. Были приняты Государственные программы борьбы с преступностью и коррупцией, две Концепции антиалкогольной государственной политики (2000 и 2010 гг.), четыре Государственные программы национальных действий по предупреждению и преодолению пьянства и алкоголизма, два Комплексных плана по противодействию незаконному обороту наркоти- ков и профилактике их потребления на 20152018 гг., которые придали государственной антидевиантной политике в значительной степени системный и комплексный характер, способствовали повышению социальной эффективности предупреждения антиобщественных явлений и борьбы с ними, укреплению общественной безопасности. К таким программам относится Государственная программа «Здоровье народа и демографическая безопасность Республики Беларусь» на 2016-2020 годы [Государственная программа... web].

Необходимым условием реализации эффективной государственной антидевиантной политики является ее научная обоснованность, комплексность и реалистичность, что предопределяет большую значимость социологической информации об уровне, особенностях, причинах и условиях, детерминирующих преступность, коррупцию, пьянство, алкоголизм, наркоманию и другие антиобщественные явления, а также о мерах по их социальному контролю. Все эти проблемы составляют предметное содержание новой отрасли социологической науки - социальной девиантологии. Важной особенностью современной социальной девиантологии является использование междисциплинарного социологического, криминологического и правового теоретико-методологического подхода к комплексному изучению 
антиобщественных явлений [Кудрявцев 1992; Гилинский 2004]. В этой связи большое значение имеет разработка системы количественных и качественных показателей социально-девиантологического мониторинга преступности и других антиобщественных явлений, а также разработка новой социологической теории этиологии (генезиса и детерминации) негативных социальных девиаций.

В современной социальной девиантологии при объяснении особенностей этиологии негативных социальных девиаций доминирует детерминационный подход, основанный на принципе детерминизма как форме взаимодействия, взаимосвязи и взаимовлияния факторов природного и социального мира. В последнее десятилетие разработана авторская теория деструктивной личностно-социальной интеракции (взаимодействия), объясняющая закономерности этиологии антиобщественных явлений. В качестве теоретической парадигмы данной теории выступает социально-детерминационный методологический подход, согласно которому первоосновой исследования генезиса и детерминации преступности и других антиобщественных явлений выступает не социум, а личность и система личностно-социальных взаимодействий. Эта система формируется на макро-, мезо-, микро-, ситуативном, групповом и межличностном уровнях, испытывая на себе влияние и одновременно оказывая воздействие на экономические, политические, социальные и культурные структуры. Личностно-социальное взаимодействие (интеракция) является формой реализации сущностных и предметно-содержательных характеристик личности и общества, системы личностных качеств и свойств и системы социальных структур, институтов, отношений и процессов. Характер и специфика взаимодействия являются источником процесса социальной детерминации преступности и других антиобщественных явлений. При изучении этиологии социальных девиаций традиционно используются такие категории, как социальная адаптация и дезадаптация, социокультурная солидарность и аномия, социализация и десоциализация, социальная интеграция и дезинтеграция. Мы предлагаем использовать категорию «личностно-социальная интеракция (взаимодействие)», которая, во-пер- вых, системно соединяет личность и общество, во-вторых, сохраняет их самостоятельную субъектность и обеспечивает социальную активность и развитие личности и социума, как в позитивном, так и в негативном направлении [Барановский 2013].

Научное знание сущности и закономерностей происхождения и развития антиобщественных явлений служит основой теоретического конструирования и социально-практического использования инновационной модели системы социальной профилактики антиобщественных явлений. Как свидетельствуют социологические исследования, антиобщественные проявления имеют социо-антропо-правовую природу и полидетерминированный экономический, социальный, культурный, правовой и биопсихологический характер генезиса и развития. Следовательно, работа по их профилактике и противодействию должна быть системной и социальной по своей сущности, являться составной частью государственной социальной политики [Яковлев 2001; Шестаков 2001].

Социологическое измерение и оценка социальной эффективности функционирования государственной системы обеспечения общественной и личной безопасности в Республике Беларусь свидетельствуют, что, несмотря на значительные достижения в данной сфере государственной деятельности, за последние два десятилетия криминальная и другие социально-девиантные ситуации продолжают оставаться сложными.

Преступность как наиболее общественно опасная форма антиобщественных явлений, несмотря на устойчивую тенденцию значительного снижения (в 1,6 раза по сравнению с 2000 г.), все еще превышает показатель 1990 г. (в 1,14 раза) и остается серьезной социально-правовой проблемой, требующей дальнейшей активизации антикриминальной деятельности правоохранительных и других государственных органов, общественных объединений и граждан. Речь идет прежде всего о выявлении и противодействии латентной преступности, повышении уровня раскрываемости преступлений, борьбе с насильственной преступностью, коррупцией, преступлениями, связанными с наркотиками и другими правонарушениями. 
С состоянием и динамикой преступности тесно взаимосвязаны пьянство и алкоголизм, причиняющие обществу огромный ущерб не только материального, но и морального плана. Данные статистики производства и потребления алкогольных напитков в Беларуси (с 2000 по 2018 г.) были проанализированы с целью выявления основных тенденций. Можно констатировать, что неблагоприятная алкогольная ситуация сегодня сохраняется. Реальный уровень потребления населением алкогольных напитков составляет 16-17 литров абсолютного алкоголя на душу населения. Этот показатель в два раза выше европейского, который был определен Всемирной организацией здравоохранения (ВО3) как критический для благоприятного социально-экономического, демографического и культурного развития страны (8 литров на душу населения). Согласно данным ВО3, опубликованным в 2016 г., в мировом рейтинге по уровню потребления алкоголя на душу населения (в возрасте от 15 лет) Беларусь находится на 27-м месте в мире с показателем 11,2 литра абсолютного алкоголя.

На наркологическом учете в органах здравоохранения страны в 2016 г. находилось 179, 6 тыс. чел., или в расчете на 100 тыс. чел. населения - 1889,2 человека. Численность больных алкоголизмом, находящихся на учете, для сравнения: в 1990 г. - 145,9 тыс. чел., или в расчете на 100 тыс. чел. населения 1431,7 чел., а в 2000 г. - 142,6 тыс. чел., или в расчете на 100 тыс. чел. населения 1825,8 человек. Таким образом, имеет место рост по сравнению с 1990 г. - в абсолютных цифрах на $23 \%$, или на $32 \%$ в расчете на 100 тыс. чел. населения, а по сравнению с 2000 г. - рост в абсолютных цифрах на $26 \%$, или на $4 \%$. По оценкам белорусских экспертов реальное число лиц, страдающих патологической зависимостью от алкоголизма, в 45 раз больше, чем находящихся на наркологическом учете в органах здравоохранения страны (то есть составляет около 700900 тыс. человек).

Вредное употребление алкоголя является существенным фактором различных болезней и третьим фактором риска, вызывающим преждевременные случаи смерти. Так, численность умерших от случайных отравлений ал- коголем в стране в 2016 г. составила 1461 чел., или в расчете на 100 тыс. чел. населения 15,4 чел., в том числе среди лиц трудоспособного возраста - 1075 чел., или 19,7 чел. (для сравнения: в 2002 г. - число умерших от алкоголя составляло 2658 чел., или 26,9 чел. на 100 тыс. чел. населения, а среди лиц трудоспособного возраста - 2103 чел., или 35,7 чел. на 100 тыс. чел. населения, то есть в 2016 г. на $43 \%$ меньше, а среди лиц трудоспособного возраста - меньше на $45 \%$ ). Таким образом, несмотря на положительную динамику, общее число жертв от случайного отравления алкоголем продолжает оставаться большим и занимает второе место после самоубийств (в частности, за пять месяцев 2018 г. от отравления алкоголем умерло 600 человек).

Употребление алкоголя находится в тесной причинно-следственной связи с совершением преступлений и других правонарушений. Так, в 2016 г. каждое четвертое преступление (16 584 преступления из 92943 всех зарегистрированных преступлений - 25,1\%) было совершено в нетрезвом состоянии, особенно семейно-бытовые и тяжкие насильственные преступления (около $75 \%$ ). Для сравнения отметим, что в 2010 г. $-17,6 \%$, в 2005 г. $14,2 \%$, в 2001 г. - 11,3 \% преступлений совершалось в состоянии алкогольного опьянения. При этом в 2010 г. $9 \%$, а в 2016 г. 6 \% потерпевших в момент совершения в отношении их преступлений находились в нетрезвом состоянии. Что касается экономической целесообразности производства и потребления населением алкогольных напитков, то по расчетам белорусских экспертов уровень затрат, связанных с пьянством и алкоголизмом, в 2013 г. составил $4,3 \%$ от ВВП, а доходы, полученные за счет реализации алкогольной продукции, составили только $1,4 \%$ от ВВП.

Общую статистическую панораму алкогольной ситуации в стране дополняют результаты мониторинговых социологических исследований, проведенных Институтом социологии НАН Беларуси в 2005-2017 годах. По данным социологических опросов потребление алкогольных напитков в стране имеет массовый и устойчивый характер. Оно распространено практически среди всех социально-демографических групп населения и во всех регионах страны. Употребляет спиртные напит- 
ки абсолютное большинство взрослого населения (по данным опроса 2005 г. - $77 \%$, 2007 г. -74 \%, 2010 г. $-72 \%, 2013$ г. $-89,4 \%$, 2017 г. $-73,2 \%$.).

Структура потребления алкогольных напитков среди взрослого населения является достаточно однородной: крепкие алкогольные напитки (коньяк, водка, самогон и т. п.) - употребляют $32 \%$ респондентов (в селе - $37 \%$, в городе - $28 \%$ ); крепленое вино - $6 \%$ респондентов (в селе $-8 \%$, в городе - $5 \%$ ); напитки средней крепости (сухое вино, шампанское и т. п.) - $33 \%$ (в селе - $31 \%$, в городе $35 \%$ ); слабоалкогольные напитки (пиво, джинтоник и т. п.) - $29 \%$ (в селе - $24 \%$, в городе - $32 \%$ ). Таким образом, высокий удельный вес потребления населением крепких спиртных напитков (32 \%, в сельской местности $-37 \%$ в два раза превышает установленный экспертами ВО3 оптимальный европейский 15-процентный показатель душевого потребления алкоголя.

В структуре мотивов (психологических причин) потребления населением алкогольных напитков преобладают следующие: застольные традиции, обычаи - 38,7 \%, для поднятия настроения, веселья, развлечения - 21,2\%, чтобы расслабиться, снять усталость $(18,5 \%)$, за компанию $(14,3 \%)$, чтобы отвлечься от проблем $(8,3 \%)$, и др. Таким образом, практически для всех социально-демографических групп населения в мотивации употребления алкогольных напитков на первый план выступают культурно-традиционные, психофизиологические и социально-психологические факторы, связанные с рассмотрением употребления алкоголя как культурной традиции бытового застолья, «компанейства» и средства восстановления физического и психического здоровья.

Среди населения преобладает культурно-традиционное употребление алкогольных напитков $(43,7 \%)$, далее следует здоровый и трезвый образ жизни, исключающий употребление алкоголя $(34,9 \%)$, и бытовое пьянство $(19,9 \%$, в том числе: вредное эпизодическое злоупотребление алкогольными напитками $10,3 \%$, вредное регулярное злоупотребление алкогольными напитками $-8,2 \%$ и вредное систематическое злоупотребление алкогольными напитками - 1,4 \%). Взрослое населе- ние, практикующее регулярное и систематическое злоупотребление алкогольными напитками $(9,6 \%)$, можно отнести к группе патологической зависимости от алкоголя (фактически около 700 тыс. человек). Сравнительный анализ этих показателей и результатов опросов 2005, 2007 и 2010 гг. показывает, что, с одной стороны, наблюдается позитивная тенденция все большего распространения среди населения повседневной практики здорового и трезвого образа жизни, исключающего употребление алкогольных напитков (c 23,0 \% в 2005 г. до 34,9 \% в 2017 г.), которая происходит за счет сокращения удельного веса культурно-традиционного употребление алкогольных напитков (с 57 \% в 2005 г. до 43,7\%). С другой стороны, распространенность среди населения так называемого бытового пьянства фактически не изменилась (в 2005 г. - $20 \%$, в 2007 г. $19 \%$, в 2010 г. $-15 \%$, в 2017 г. - 19,9\%). Это дает основание прогнозировать сохранение такой же достаточно тревожной ситуации с распространенностью пьянства и алкоголизма. Изменить ситуацию способна принципиально новая стратегия государственной антиалкогольной политики, направленная прежде всего на профилактику пьянства и алкоголизма и противодействие этим явлениям. Разработка этой стратегии необходима в ближайшей перспективе.

На рисунке представлены (в порядке убывания) факторы, которые влияют на распространенность пьянства и алкоголизма в современной Беларуси, по данным опроса, проведенного Институтом социологии НАН Беларуси [Барановский, Осипчик, Пилипенко 2016].

На первом месте оказываются экономические, социальные и социокультурные причины распространенности пьянства и алкоголизма, что свидетельствует о неэффективности государственной антиалкогольной политики и работы государственных структур и общественности по профилактике и противодействию этим антиобщественным явлениям. Значительная часть населения недооценивает степень вреда, который может причинить здоровью употребление алкоголя. Население достаточно лояльно и, можно сказать, одобрительно относится к употреблению алкогольных напитков как социальному 


\section{БЕЛОРУССКАЯ АКАДЕМИЧЕСКАЯ СОЦИОЛОГИЯ}

явлению, культуре застолья и обыденного образа жизни. Большинство опрошенных не собирается в ближайшем будущем уменьшить регулярность и количество или полностью отказаться от употребления алкогольных напитков (только $8 \%$ респондентов согласны в ближайшем будущем вести здоровый образ жизни, исключающий употребление алкоголя). При этом в общественном сознании здоровый образ жизни не ассоциируется с полным отказом от употребления алкогольных напитков, а допускается сочетание с социальной практикой культурно-традиционного потребления алкоголя и атрибута культуры праздничного застолья, общения, снятия физического и психологического напряжения и стресса.

Эти обстоятельства, к сожалению, не учитывает действующая в стране стратегия государственной антиалкогольной политики, согласно которой здоровый образ жизни трактуется как поведение, исключающее употребление алкоголя, что фактически приводит к его отождествлению с трезвым образом жизни оторванным от реальной жизни и культуры обыденного поведения большинства населения социальным мифом.

Население страны в настоящее время невысоко оценивает эффективность деятельности государства по профилактике пьянства и алкоголизма и борьбе с ними. Неудовлетворительно ее оценивает треть опрошенных $31,5 \%$, удовлетворительно - 31,0 \%, положительно - только 9,8 \% респондентов, остальные с ответом затруднились.

Превентивная стратегия социального предупреждения и снижения уровня потребления спиртных напитков является наиболее эффективной государственной антиалкогольной политикой. Такая стратегическая политика должна предусматривать формирование культуры потребления алкогольных напитков населением, ценностных и поведенческих стереотипов социально-позитивного и здорового образа жизни, эффективные меры противодействия пьянству и алкоголизму, а также учитывать социальную природу данных форм социального поведения. Такая стратегия предупреждения пьянства и алкоголизма, борьбы с этими негативными явлениями реализуется в различных

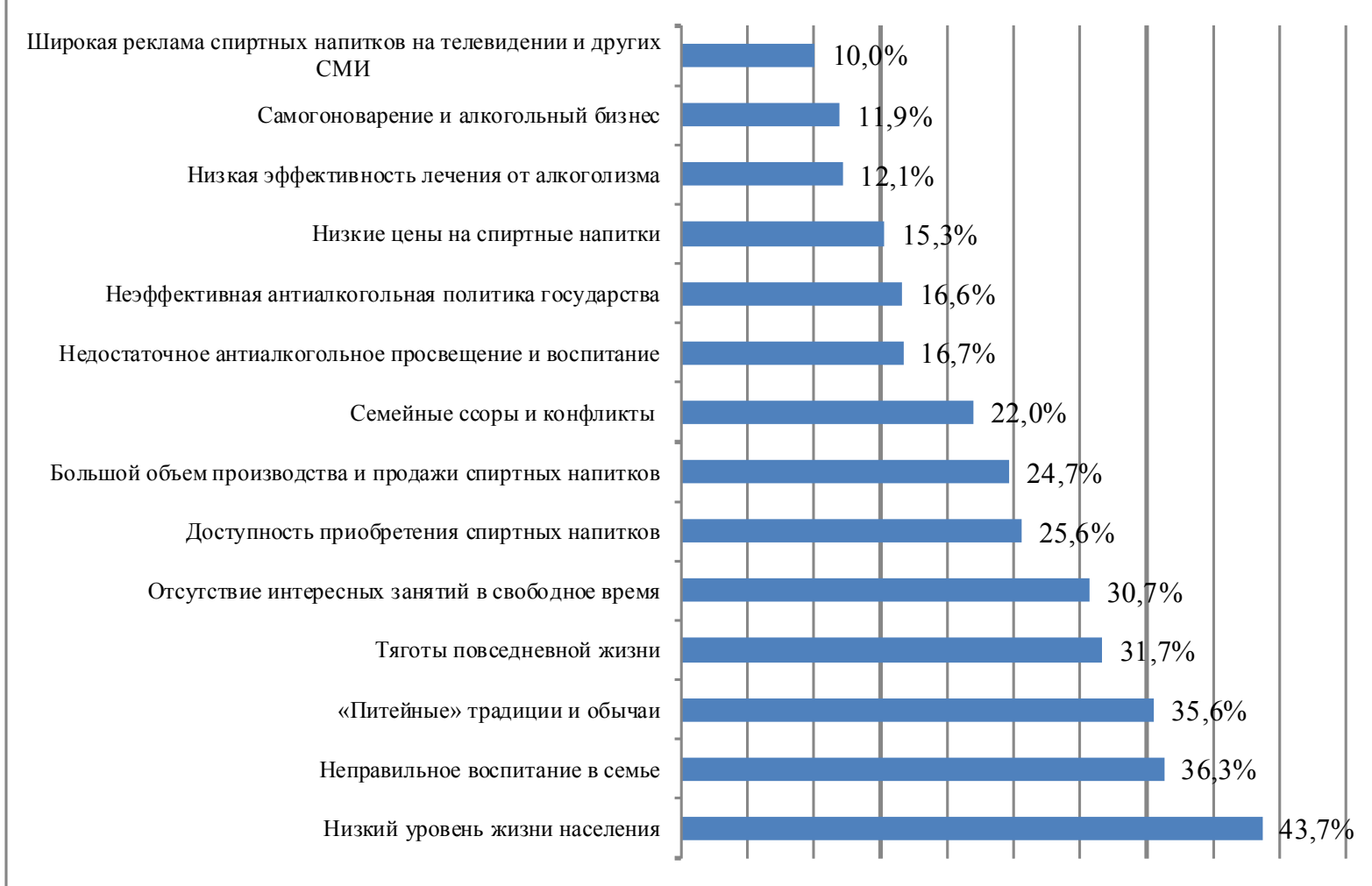

Факторы, влияющие на распространенность пьянства и алкоголизма в Беларуси 
странах мира, предусмотрена Европейским планом действий по сокращению вредного употребления алкоголя на период 2012-2020 годов.

Таким образом, социально-экономическая и культурная ситуация в Республике Беларусь диктует необходимость принципиального изменения теоретико-концептуальной основы современной государственной антиалкогольной политики. Комплексное социальное предупреждение и снижение уровня потребления спиртных напитков, реализуемое в контексте формирования культуры потребления алкогольных напитков населением, должно прийти на смену неэффективной политике, основанной на методах запрета и наказаний. Государственная антиалкогольная политика должна предусматривать меры по замещению и вытеснению пьянства и алкоголизма другой социально-позитивной, трудовой, семейно-бытовой и досуговой деятельностью. Это может быть достигнуто за счет создания благоприятных экономических, социальных и культурных условий и стимулирования социально-позитивного и здорового образа жизни. Этот комплекс мер не исключает необходимость поддержания социально-правового порядка, ответственности и наказания, а также лечения и реабилитации лиц, страдающих алкоголизмом.

Актуальной и социально востребованной является проблема профилактики потребления наркотиков, наркомании и незаконного оборота наркотиков (наркотизма), а также противодействия этим явлениям. Проблема наркотизма в Беларуси продолжает оставаться напряженной и вызывает серьезную тревогу и беспокойство со стороны государства, общественности и населения.

Анализ данных статистики Министерства здравоохранения Республики Беларусь показывает, что в настоящее время на наркологическом учете находится значительная численность лиц, патологически зависимых от употребления наркотиков - 12725 чел. по состоянию на 1 июля 2018 года. Что касается динамики наркотизации населения, то на протяжении последних почти пятнадцати лет (с 2004 по 2018 г.) прослеживается тенденция увеличения численности лиц, состоящих на наркологическом учете Министерства здравоохранения Республики Беларусь: с 9468 чел. в 2004 г. до 12725 чел. в 2018 г. - прирост составляет $34,4 \%$. При этом, если в первое десятилетие имел место значительный рост числа лиц, находящихся на наркологическом учете (до 15527 чел. в 2015 г.), то начиная с 2016 г. отмечается устойчивая положительная тенденция к его сокращению - на 18,0 \% (до 12725 чел. на 1 июля 2018 г.).

Изучение данных уголовной статистики свидетельствует, что за последние четырнадцать лет количество преступлений, связанных с наркотиками, несколько сократилось: с 6630 преступлений в 2004 г. до 5387 преступлений в 2017 г. - то есть на $18,7 \%$. Вместе с тем удельный вес преступлений, связанных с наркотиками, в общем количестве зарегистрированной преступности за данный период не изменился и по-прежнему составляет $6,0 \%$.

По информации, которая представлена в сборнике «Современное состояние наркологической ситуации в Республике Беларусь», подготовленном Гродненским медицинским университетом в 2012 г., в стране примерно 1,1$1,3 \%$ взрослого населения употребляет наркотики, то есть примерно от 82500 до 97500 человек [Лелевич и др. 2012].

По данным социологического исследования, проведенного Институтом социологии НАН Беларуси в октябре 2017 г., потребление наркотиков распространено среди $1,7 \%$ взрослого населения. Эта свидетельствует о достаточно высоком уровне распространенности потребления наркотиков в стране и негативной тенденции его роста - в 1,4 раза за последние шесть лет.

Таким образом, официальная статистическая медицинская и уголовная информация не в полной мере отражает реальную наркотическую ситуацию в стране, так как она, прежде всего, не учитывает так называемый латентный наркотизм, который можно рассчитать следующим образом. Как уже упоминалось, по данным социологического исследования потребление наркотиков распространено среди 1,7 \% взрослого населения страны. Одновременно с этим еще 3,9 \% опрошенных отметили, что они «ранее пробовали, но сейчас не употребляют наркотики». Следовательно, в совокупности в сферу так называемого пробования и употребления наркотиков вовле- 
чено 5,6 \% взрослого населения страны, то есть примерно 420 тыс. человек. Одновременно с этим 8,5 \% всех опрошенных указали, что в их ближайшем социальном окружении (среди родственников, знакомых, коллег по работе и учебе, приятелей и друзей) имеются лица, которые употребляют наркотики. Социологическая информация о распространенности потребления наркотиков в ближайшем социальном окружении респондентов дает основание полагать, что реальные масштабы употребления наркотиков превышают выявленный показатель в $1,7 \%$.

Возможен вариант оценки уровня латентной наркомании - патологической формы употребления наркотиков, при котором учитывается только число лиц, которые употребляют тяжелые наркотики и фактически должны быть отнесены к категории лиц, нуждающихся в наркологическом учете (их общая численность по данным социологического опроса составляет $0,8 \%$ всех респондентов, то есть примерно 60 тысяч человек). Если соотнести эту категорию респондентов с численностью лиц, находящихся на 1 января 2018 г. на наркологическом учете Министерства здравоохранения Республики Беларусь- 13093 чел., то уровень латентной наркомании - патологической формы употребления наркотиков - составляет 46,9 тыс. чел., то есть в 3,6 раз больше числа лиц, находящихся на наркологическом учете, что свидетельствует о недостаточной эффективности функционирования системы медицинского наркологического учета в стране.

По расчетам Министерства внутренних дел Республики Беларусь, проведенным в 2018 г., уровень латентности наркомании в 6,8 раза выше официальных статистических медицинских и правоохранительных данных и составляет 88,5 тыс. человек. По оценкам экспертов УНП ООН реальное число наркозависимых лиц в 7-10 раз превышает официальную статистику, то есть если использовать эти расчеты, то в Беларуси численность наркозависимых свыше 18 лет составляет примерно от 89 тыс. до 127 тыс. человек. Разница в указанных показателях в некоторой степени может быть объяснена различиями в используемой терминологии, при которой часто допускается смешивание таких понятий, как «употребление наркотиков», «наркомания», «наркозависимые» и др.
По данным Всемирной организации здравоохранения в мире около $1 \%$ всего населения регулярно употребляет наркотики. По критериям ВО3, если доля наркоманов в структуре населения превышает $7 \%$, это свидетельствует о необратимых процессах деградации общества. По результатам проведенного в октябре 2017 г. социологического опроса, согласно которым 1,7\% респондентов употребляют наркотики, 3,9 \% - пробовали наркотики, а у 8,5 \% в ближайшем социальном окружении имеются лица, которые употребляют наркотики, можно сделать вывод о наличии достаточно тревожной наркотической ситуации в нашей стране. Для сравнения отметим, что по оценкам экспертов в России имеет место еще более неблагополучная наркотическая ситуация - от 3 до 5 \% населения регулярно употребляют наркотики.

Автором разработаны меры по совершенствованию профилактики наркотизма в стране, а также его противодействию. Прежде всего, на концептуально-стратегическом, законодательном и социально-практическом уровнях следует придать государственной и общественной антинаркотической профилактической работе системный, комплексный и социально эффективный характер. Антинаркотическую профилактическую работу целесообразно рассматривать как составную часть и одно из приоритетных направлений государственной социальной политики и общей системы предупреждения преступности и других антиобщественных явлений.

Следует разработать стратегию государственной антинаркотической политики и на ее основе общенациональную и региональные программы мероприятий по профилактике и противодействию наркотизму. Обеспечить полномасштабное статистическое и научное информационное изучение состояния и динамики зарегистрированной, латентной и реальной наркотической ситуации в режиме ежегодного мониторинга. Осуществлять дифференцированный подход к профилактике наркотизма с учетом особенностей его четырех форм: a) эпизодического немедицинского употребления наркотиков - как преимущественно социокультурной проблемы; б) наркомании - патологической формы немедицинского употребления наркотиков - как преимущественно со- 
циально-медицинской проблемы; в) незаконного производства и распространения наркотиков; г) преступлений и других правонарушений, связанных с наркотиками, - как преимущественно социально-правовой проблемы.

Антинаркотическую профилактическую работу необходимо осуществлять на следующих основных этапах: а) донаркотическая профилактика - выявление и профилактическая работа с лицами, качества, поведение и образ жизни которых свидетельствуют о социально-психологической и поведенческой предрасположенности к употреблению наркотиков, занятию наркобизнесом или совершению преступлений, связанных с наркотиками, группами наркотического риска, их неблагополучным социальным окружением, а также всем населением страны; б) наркотическая профилактика - работа с лицами, практикующими немедицинское употребление наркотиков, наркоманами, лицами, занимающимися наркобизнесом или совершающими преступления и другие правонарушения, связанные с наркотиками; в) постнаркотическая профилактика - работа с лицами, прошедшими курс лечения от наркотической зависимости, а также лицами, отбывшими уголовное наказание за преступления, связанные с наркотиками, до их выздоровления, исправления и законопослушного поведения.

Большое значение имеет обеспечение комплексности мер: а) «общей профилактики» наркотизма как массового антиобщественного социального явления; б) «специальной профилактики» (профилактика отдельных форм наркотизма, а также наиболее общественно опасных категорий лиц, употребляющих наркотики); в) «индивидуальной профилактики» образа жизни и ближайшего социального окружения лиц, употребляющих наркотики, а также лиц из групп наркотического риска.

Важно оптимально сочетать меры: а) «первичной профилактики»-выявление и профилактическая работа с лицами, качества, поведение и образ жизни которых свидетельствует о социально-психологической и поведенческой предрасположенности к употреблению наркотиков, занятию наркобизнесом или совершению преступлений и других правонарушений, связанных с наркотиками, группами наркотического риска, их неблагополучным соци- альным окружением, а также всем населением страны; б) «вторичной профилактики»работа с лицами, практикующими немедицинское употребление наркотиков, наркоманами, лицами, занимающимися наркобизнесом или совершающими преступления и другие правонарушения, связанные с наркотиками; в) «третичной профилактики» - работа с лицами, прошедшими курс лечения от наркотической зависимости, отбывшими уголовное наказание за преступления, связанные с наркотиками, до их выздоровления, исправления и законопослушного поведения.

Следует осуществить разработку организационно-управленческих технологий и методических материалов по профилактике различных форм наркотизма, включая эффективное взаимодействие между всеми субъектами антинаркотической профилактической работы. Рассмотреть вопрос о создании таких структур, как: специализированный вневедомственный Научно-исследовательский институт криминологии, социальной девиантологии и виктимологии; Национальный комитет по предупреждению преступности и других антиобщественных явлений как постоянно действующий организационно-управленческий государственный орган, отвечающий за разработку направлений и координацию всех субъектов социально-правовой системы предупреждения преступности, пьянства, наркомании и других антиобщественных явлений.

В системе антидевиантной политики приоритетным направлением должна быть деятельность по предупреждению антиобщественных явлений [Шипунова 2006]. Опыт многих стран свидетельствует об эффективности государственной антидевиантной политики, построенной на принципе системного предупреждения антиобщественных явлений.

Реализуя социальные технологии, важно учитывать цели системы профилактики антиобщественных явлений и направления деятельности по профилактике антиобщественных явлений, а также разработать меры профилактики антиобщественных явлений. Система социальной профилактики антиобщественных явлений должна быть направлена на интеграцию общесоциальной, социально-девиантной, виктимологической, 
правовой и социально-реинтеграционной профилактической деятельности государственных органов, общественных организаций и граждан, предусматривать следующие уровни социальной субъектности: социальный (макросоциальный, мезосоциальный, микросоциальный); ситуационный; личностно-девиантный; личностно-виктимный; личностно-социально-интеракционный [Давыдов, Чураков 2000].

Социальная профилактика антиобщественных явлений включает: общие меры социальной профилактики; специальные меры социальной профилактики; индивидуальные меры социальной профилактики [Овчинский, Кондратюк, Горяинова (ред.) 2008; Алексеев, Герасимов, Сухарев 2001].

Практическая реализация предлагаемых теоретических и научно-прикладных инноваций будет способствовать формированию в стране современной системы социальной профилактики антиобщественных явлений, позволит снизить распространение и сгладить негативные последствия антиобщественных явлений, тем самым содействуя социальноэкономическому, демографическому, социальному и культурному развитию современного белорусского общества.

\section{СПИСОК ЛИТЕРАТУРЫ}

Алексеев, Герасимов, Сухарев 2001 - Алексеев А.И., Герасимов С.И., Сухарев А.Я. Криминологическая профилактика: теория, опыт, проблемы: монография. М.: Норма, 2001.

Барановский, Осипчик, Пилипенко 2016 - Барановский Н.А., Осипчик С.И., Пилипенко Е.В. Проблема пьянства и алкоголизма в социологическом измерении // Социологический альманах. 2016. № 7. С. 81-92.

Барановский 2013 - Барановский Н.А. Этиология преступности в контексте социально-детерминационного анализа // Доклады Национальной академии наук Беларуси. 2013. Т. 57, № 5. С. $108-116$

Гилинский 2004 - Гилинский Я.Г. Девиантология: социология преступности, наркотизма, проституции, самоубийств и других «отклонений». СПб.: Юрид. центр Пресс, 2004.

Государственная программа... web - Государственная программа «Здоровье народа и демографическая безопасность Республики Беларусь» на 2016-2020 годы: угв. постановлением Совета Министров Республики Беларусь, 14 марта 2016 г., № 200 // http://www.government.by/ upload/docs/filecdf0f8a76b95e004.PDF.

Давыдов, Чураков 2000 - Давыдов А.А., Чураков А.Н. Модульный анализ и моделирование социума. М.: ИС РАН, 2000.

Кудрявцев 1992 - Кудрявцев В.Н. Социальные деформации. Причины, механизмы и пуги преодоления. М.: Изд-во ИГ и ПРАН, 1992.

Лелевич и др. 2012 - Лелевич В.В., Виниикая А.Г., Лелевич С.В., Разводовский Ю.Е. Современное состояние наркотической ситуации в Республике Беларусь. Минск, 2012.

Овчинский, Кондратюк, Горяинова (ред.) 2008 Овчинский В.С., Кондратюк Л.В., Горяинова К.К. (ред.). Криминологическое измерение. М.: Норма, 2008.

Шестаков 2001 - Шестаков Д.А. Криминология. Преступность как свойство общества. СПб.: Санкт-Петербургский гос. ун-т; Изд-во «Лань», 2001.

Шипунова 2006 - Шипунова Т.В. Подходы к объяснению преступности: противостояние или взаимодополнение (взгляд социолога) // Социологические исследования. 2006. № 1 (261). C. 89-98.

Яковлев 2001 - Яковлев А.М. Социология преступности (криминология): Основы общей теории: учеб. пособие. М.: Содействие новый век, 2001.

\section{REFERENCES}

Alekseev A.I., Gerasimov S.I., Sukharev A.Ya., 2001. Criminological prevention: theory, experience, problems. Monograph. Moscow, Norm.

Baranovsky N.A., Osipchik S.I., Pilipenko E.V., 2016. The problem of drunkenness and alcoholism in the sociological dimension. Sociological almanac, no. 7, pp. 81-92.

Baranovsky N.A., 2013. The etiology of crime in the context of socio-determination analysis. Reports of the National Academy of Sciences of Belarus, vol. 57, no. 5, pp. 108-116.

Gilinsky Ya.G., 2004. Deviantologiya: sociology of crime, drug addiction, prostitution, suicides and other "deviations". Saint Petersburg, Yurid. Press center.

The state program "Health of the people and demographic safety of Republic of Belarus" for 2016-2020. URL: www.government.by/upload/ docs/filecdf0f8a76b95e004.PDF.

Davydov A.A., Churakov A.N., 2000. Modular analysis and modeling of society. Moscow, IS RAS. 
Н.А. Барановский. Социальная профилактика антиобщественных явлений в системе антидевиантной политики

Kudryavtsev V.N., 1992. Social deformations. Reasons, mechanisms and ways of overcoming. Moscow, IS publishing house and PRANAS.

Lelevich V.V., Vinitskaya A.G., Lelevich S.V., Razvodovsky Yu.E., 2012. Current state of a narcotic situation in Republic of Belarus. Minsk.

Ovchinsky V.S., Kondratyuk L.V., Goryainova K.K. (eds.), 2008. Criminological measurement. Moscow, Norm.
Shestakov D.A., 2001. Criminology. Crime as property of society. Saint Petersburg, The St. Petersburg state. un-t, Publishing house Lan.

Shipunova T.V., 2006. Approaches to a crime explanation: opposition or complementarity (sociologist's look). Social researches, no. 1 (261), pp. 89-98.

Yakovlev A.M., 2001. Crime sociology (criminology): Bases of the general theory: studies. grant. Moscow, Assistance new century.

\section{Information about the Author}

Nikolai A. Baranovsky, Doctor of Sciences (Sociology), Associate Professor, Chief Researcher, Institute of Sociology of the National Academy of Sciences of Belarus, Surganova St., 1/2, 220072 Minsk, Republic of Belarus, nicolai2003@inbox.ru, https://orcid.org/0000-0002-6162-8163

\section{Информация об авторе}

Николай Александрович Барановский, доктор социологических наук, доцент, главный научный сотрудник Института социологии НАН Беларуси, ул. Сурганова 1/2, 200072 г. Минск, Республика Беларусь, nicolai2003@inbox.ru, https://orcid.org/0000-0002-6162-8163 